\title{
Analisis POM QM V5.2 For Windows pada Penerapan Metode $A B C$ dan EOQ Dalam Pengendaliaan Persediaan Bahan Baku PVC Compound (Studi Kasus PT.SMI)
}

Amin Widodo ${ }^{{ }^{*}}$, Achmad Hindasyah ${ }^{2}$, Makhsun Makhsun ${ }^{3}$

1)Program Pasca Sarjana (S2) Magister Komputer, Program Sudi Teknik Informatika,

Sekolah Tinggi Manajemen Informatika dan Komputer Eresha

2) Badan Tenaga Nuklir Nasional

*Email: aminwidodo80024@gmail.com

Info Artikel

Kata Kunci :

$A B C, E O Q, P O M Q M$ V5.2 For Windows

Keywords :

$A B C, E O Q$, POM QM V5.2 For

Windows

\section{Tanggal Artikel}

Dikirim : 04 November 2020

Direvisi : 20 November 2020

Diterima : 30 November 2020

\section{Abstrak}

PT.SMI Perusahaan konsisten dalam menerapkan ISO 9001:

2015 dalam upaya tersebut yang dilakukan perusahaan yaitu menginginkan pengendalian persediaan lebih terpola. Tujuan penelitian untuk mengetahui bahan baku yang membutuhkan monitoring sangat ketat dengan Metode $A B C$ dan EOQ. Metode penelitian yang digunakan kuantitatif, diskriptif dengan cara observasi dan wawancara, metode untuk penyeselesaian Riset Operasi menggunakan perangkat lunak berbasis POM QM V5.2 For Windows. Hasil observasi data kebutuhan bahan baku, biaya persediaan akan di lakukan proses pengolahan data dengan menggunakan metode inventory $A B C$ dan $E O Q$ dengan bantuan Tools teknologi informasi POM QM V5.2 For Windows, Hasil penelitian $A B C$ Analisys menujukan bahan baku yang membutuhkan monitoring sangat ketat yaitu PVC 66, Stabilizer, dan PVC 71, Lubricant 16A, dan Lubricant 15 . Hasil penelitian Metode EOQ berpengaruh positif, keuntungan perusahaan akan meningkat karena terjadi efisiensi biaya pembelian bahan baku yaitu PVC 66 menghemat biaya rata-rata $\mathrm{Rp}$ 96.321.440,00 atau 44\%, Stabilizer menghemat biaya rata-rata $\mathrm{Rp}$ 4.634.959,00 atau 57\%, PVC71 menghemat biaya rata-rata Rp 49.304.566.00 atau 38\%, Lubricant 16A menghemat biaya rata-rata Rp 869.640,7 atau 38\%, Lubricant 15 menghemat biaya rata-rata Rp 1.663.651,38 atau 60\%.

\footnotetext{
Abstarct

PT. The SMI of the Company is consistent in the application of ISO 9001: 2015, in this effort the company does, namely wanting a more patterned inventory control. The research objective is to find out the raw materials that require very strict monitoring with the $A B C$ and $E O Q$ methods. The research method used is quantitative, descriptive by means of observation and interviews, the method for completing Operations Research using software based on POM QM V5.2 For Windows. The results of the observation of data on raw material requirements, inventory costs will be processed using the $A B C$ and $E O Q$ inventory methods with the help of information technology tools POM QM V5.2 For Windows, the results of $A B C$ Analisys research show that raw materials that require very strict monitoring are PVC 66. , Stabilizer, and PVC 71, Lubricant $16 \mathrm{~A}$, and Lubricant 15 . The results of the EOQ method research have a positive effect, company profits will increase due to the efficiency of the cost of purchasing raw materials, namely PVC 66 which saves an average of Rp. $96,321,440.00$ or $44 \%$, Stabilizer saves an average of IDR 4,634,959.00 or $57 \%$, PVC 71 saves an average of IDR 49,304,566.00 or 38\%, Lubricant $16 \mathrm{~A}$ saves an average of IDR $869,640.7$ or $38 \%$, Lubricant 15 saves costs an average of IDR $1,663,651.38$ or $60 \%$.
} 


\section{PENDAHULUAN}

Sistem manajemen mutu ISO 9001:2015 telah diterapkan di PT. SMI dengan konsisten, memberikan pelayanan dan hasil produk yang berkualitas. Sistem manajemen mutu diterapkan untuk meyakinkan konsumen bahwa produk yang dihasilkan perusahaan mampu memenuhi persyaratan dari pembeli dan meningkatkan loyalitas konsumen terhadap Perusahaan[1]. Dalam upaya meningkatan kepuasan pelanggan perusahaan mengharapkan selisih persentase antara kebutuhan dan pembelian hanya $15 \%$ untuk stock persedian, perusahaan membutuhkan metode untuk klasifikasi bahan baku dan memberikan prioritas pada bahan baku yang berdasarkan tingkat penyerapan modal dan dimonitoring secara ketat, perusahaan perlu menerapkan perencanaan dan pengendalian persediaan untuk mencapai tujuan yaitu persentase selisih antara pembelian dan kebutuhan dapat di tekan sesuai dengan target perusahaan.

Kerugian yang terjadi saat ini investasi pada bahan baku terlalu tinggi, sehingga biaya pemesanan dan menyimpan untuk pemeliharaan bahan selama penyimpanan untuk pemeliharaan bahan selama penyimpanan sehingga biaya yang dikeluarkan perusahaan tidak efisien dan pengendalian persediaan belum optimum[2].

Penelitian menggunakan POM-QM V5.2 For Windows untuk penyelesaian permasalahan manajemen produksi dan operasi[3], yang menggabungkan dan mengubah berbagai sumber daya yang digunakan dalam subsistem produksi,operasi organisasi menjadi produk atau layanan bernilai tambah secara terkendali sesuai dengan kebijakan organisasi[4]. output dari penelitian yaitu klasifikasi bahan baku sesuai dengan tingkat penyerapan modal mulai dari persentase penyerapan modal tertinggi ke paling rendah, persedian lebih optimum, diketahui Economic Order Quantity, dan menghasilkan titik pemesanan kembali dengan demikian biaya yang dikeluarkan perusahaan efisien[5].

\section{METODE PENELITIAN}

Metode yang diterapkan dalam penelitian ini yaitu Analisys Base Costing dan Economic Order Quantity dengan bantuan perangkat lunak berbasis POM QM V5.2 For Windows dan sebagai pembanding hasil perhitungan menggunakan manual rumus yang di input pada lembar kerja elektronik yang terdapat pada Microsoft Excel, untuk menerjemahkan hasil perhitungan ke dalam bentuk tabel[6].

Penelitian dimulai dari perumusan masalah dan tujuan penelitian, pengumpulan data yang terdiri dari data primer dan sekunder kedua data digunakan untuk memperkaya hasil penelitian, kemudian data bahan baku, kebutuhan bahan baku, jadwal kedatangan bahan baku, biaya persediaan yang mencangkup biaya pemesanan, biaya penyimpanan[5].

Pengolahan data dilakukan dengan menggunakan dua alternatif dari kedua alternatif yang digunakan untuk pertimbangan dalam evaluasi hasil penelitian. Evaluasi hasil dilakukan untuk membandingkan untuk mendapatkan alternatif terbaik yang dapat diterapkan pada perusahaan dengan hasil akhir dari penelitian biaya optimum.

\section{HASIL DAN PEMBAHASAN}

Dalam penentuan pengendalian persediaan optimum dimulai dari klasifikasi bahan baku menggunakan metode $A B C$ agar diketahui bahan baku prioritas untuk mempermudah dan memfokuskan penelitian selanjutnya dilakukan perhitungan metode EOQ kemudian dapat di hitung optimal order, annual setup cost dan reorder point.

\subsection{Klasifikasi Bahan Baku Metode ABC}

Tabel 1. Hasil klasifikasi kelas $A B C$

\begin{tabular}{|c|c|c|c|c|c|c|c|c|}
\hline \multirow{2}{*}{$\begin{array}{l}\text { Item name } \\
\text { PVC } 66\end{array}$} & \multirow{2}{*}{$\begin{array}{l}\text { Demand } \\
220,83\end{array}$} & \multicolumn{2}{|c|}{ Price } & \multicolumn{2}{|c|}{ Dollar Volume } & \multirow{2}{*}{$\begin{array}{l}\begin{array}{l}\text { Percent } \\
\text { of } \$ \text {-Vol }\end{array} \\
26,65 \%\end{array}$} & \multirow{2}{*}{$\begin{array}{l}\text { Cumultv } \\
\text { \$-vol \% }\end{array}$} & \multirow{2}{*}{$\begin{array}{c}\text { Category } \\
\text { A }\end{array}$} \\
\hline & & $\mathrm{Rp}$ & 35.500 & $\mathrm{Rp}$ & $7.839 .465,0$ & & & \\
\hline Stabilizer & 114,05 & $\mathrm{Rp}$ & 36.750 & $\mathrm{Rp}$ & $4.191 .485,0$ & $14,25 \%$ & $40,90 \%$ & $A$ \\
\hline PVC 71 & 90,64 & $\mathrm{Rp}$ & 35.300 & $\mathrm{Rp}$ & $3.199 .698,0$ & $10,88 \%$ & $51,77 \%$ & A \\
\hline Lubricant $16 \mathrm{~A}$ & 56,19 & $\mathrm{Rp}$ & 48.400 & $\mathrm{Rp}$ & $2.719 .790,0$ & $9,25 \%$ & $61,02 \%$ & A \\
\hline Lubricant 15 & 141,24 & $\mathrm{Rp}$ & 14.500 & $\mathrm{Rp}$ & $2.047 .966,0$ & $6,96 \%$ & $67,98 \%$ & A \\
\hline Pigment $B$ & 94,27 & $\mathrm{Rp}$ & 20.700 & $\mathrm{Rp}$ & $1.951 .410,0$ & $6,63 \%$ & $74,61 \%$ & B \\
\hline Stabilizer CZ & 61,01 & $\mathrm{Rp}$ & 30.500 & $\mathrm{Rp}$ & $1.860 .744,0$ & $6,33 \%$ & $80,94 \%$ & B \\
\hline Lubricant $17 \mathrm{~A}$ & 25,69 & $\mathrm{Rp}$ & 63.900 & $\mathrm{Rp}$ & $1.641 .463,0$ & $5,58 \%$ & $86,52 \%$ & B \\
\hline Pigment TI & 31,04 & $\mathrm{Rp}$ & 40.300 & $\mathrm{Rp}$ & $1.250 .751,0$ & $4,25 \%$ & $90,77 \%$ & C \\
\hline Lubricant 24 & 28,35 & $\mathrm{Rp}$ & 28.700 & $\mathrm{Rp}$ & $813.702,4$ & $2,77 \%$ & $93,54 \%$ & C \\
\hline
\end{tabular}


IJAI (Indonesian Journal of Applied Informatics)

Vol. 5 No.1 Tahun 2020 pISSN: 2548-3846, elSSN: 2598-5981

\begin{tabular}{|c|c|c|c|c|c|c|c|c|}
\hline \multirow{2}{*}{$\begin{array}{l}\text { Item name } \\
\text { Filler CY }\end{array}$} & \multirow{2}{*}{$\begin{array}{l}\text { Demand } \\
229,17\end{array}$} & \multicolumn{2}{|c|}{ Price } & \multicolumn{2}{|c|}{ Dollar Volume } & \multirow{2}{*}{$\begin{array}{c}\begin{array}{c}\text { Percent } \\
\text { of } \$ \text {-Vol }\end{array} \\
2,73 \% \\
\end{array}$} & \multirow{2}{*}{$\begin{array}{l}\text { Cumultv } \\
\text { \$-vol \% } \\
96,26 \%\end{array}$} & \multirow{2}{*}{$\begin{array}{l}\text { Category } \\
\text { C }\end{array}$} \\
\hline & & $\mathrm{Rp}$ & 3.500 & $\mathrm{Rp}$ & $802.105,5$ & & & \\
\hline Lubricant 20 & 28,07 & $\mathrm{Rp}$ & 25.500 & $\mathrm{Rp}$ & $715.836,0$ & $2,43 \%$ & $98,70 \%$ & C \\
\hline Plasticizer $P$ & 6,9 & $\mathrm{Rp}$ & 29.300 & $\mathrm{Rp}$ & $202.228,6$ & $0,69 \%$ & $99,38 \%$ & C \\
\hline Stabilizer TB & 1,1 & $\mathrm{Rp}$ & 39.800 & $\mathrm{Rp}$ & $43.700,4$ & $0,15 \%$ & $99,53 \%$ & C \\
\hline Plasticizer IP & 1,11 & $\mathrm{Rp}$ & 29.200 & $\mathrm{Rp}$ & $32.412,0$ & $0,11 \%$ & $99,64 \%$ & C \\
\hline Filler F-1 & 1,4 & $\mathrm{Rp}$ & 23.100 & $\mathrm{Rp}$ & $32.386,2$ & $0,11 \%$ & $99,75 \%$ & C \\
\hline Plasticizer T & 1,1 & $\mathrm{Rp}$ & 27.800 & $\mathrm{Rp}$ & $30.524,4$ & $0,10 \%$ & $99,86 \%$ & C \\
\hline Filler $10 \mathrm{C}$ & 10,5 & $\mathrm{Rp}$ & 2.700 & $\mathrm{Rp}$ & $28.341,9$ & $0,10 \%$ & $99,95 \%$ & C \\
\hline Plasticizer 52 & 1,16 & $\mathrm{Rp}$ & 11.800 & $\mathrm{Rp}$ & $13.735,2$ & $0,05 \%$ & $100,00 \%$ & C \\
\hline TOTAL & 1143,82 & & & Rp & $417.744,6$ & & & \\
\hline
\end{tabular}

Jumlah item yang di analisis adalah 19 bahan baku, dari hasil perhitungan $A B C$ Analisys menggunakan POMQM V5.2 For Windows masuk kategori A didapat 5 item, 3 item kategori $B$, dan 11 item kategori $C$ bahan baku yang masuk kategori $A$ akan dilanjutkan untuk menghitunga jumlah pemesan ekonomis[7]. Berikut ini kebutuhan raw material yang masuk klasifikasi selama 5 tahun:

Tabel 2. Kebutuhan Raw Material

\begin{tabular}{|c|c|c|c|c|c|c|c|}
\hline \multirow[b]{2}{*}{ No } & \multicolumn{7}{|c|}{ Year } \\
\hline & Raw Material & 2015 & 2016 & 2017 & 2018 & 2019 & Total \\
\hline 1 & PVC 66 & 39.910 .835 & 40.240 .485 & 44.309 .754 & 47.183 .583 & 49.187 .400 & 220.832 .057 \\
\hline 2 & Stabilizer & 18.742 & 21.315 & 22.511 & 24.262 & 27.224 & 114.054 \\
\hline 3 & PVC 71 & 13.800 .250 & 15.416 .030 & 16.819 .139 & 20.731 .638 & 23.876 .122 & 90.643 .179 \\
\hline 4 & Lubricant $16 \mathrm{~A}$ & 7.523 & 9.451 & 12.130 & 13.415 & 13.675 & 56.194 \\
\hline 5 & Lubricant 15 & 18.486 & 17.498 & 28.612 & 45.124 & 31.520 & 141.239 \\
\hline
\end{tabular}

Tabel 2 kebutuhan Raw Material selama 5 tahun dapat di analisis bahwa tren kebutuhan Raw Material rata-rata mengalami kenaikan dengan demikian mengambarkan bahwa perusahaan mengalami perkembangan setiap tahun.

Berikut ini biaya bahan pemesanan Raw Material setiap kali pesan selama 5 tahun;

Tabel 3. Rincian Biaya Pemesanan

\begin{tabular}{llllrr}
\hline Raw Material & $\mathbf{5}$ & \multicolumn{1}{c}{ Year } \\
& $\mathbf{2 0 1 5}$ & $\mathbf{2 0 1 6}$ & $\mathbf{2 0 1 7}$ & \multicolumn{1}{c}{$\mathbf{2 0 1 8}$} & \multicolumn{1}{c}{$\mathbf{2 0 1 9}$} \\
\hline PVC (71) & 570.290 & 685.714 & 723.214 & 700.966 & 674.370 \\
Stabilizer & 791.667 & 971.429 & 925.000 & 1.278 .125 & 1.150 .556 \\
PVC 66 & 581.391 & 690.672 & 730.814 & 780.722 & 841.936 \\
Lubricant 15 & 166.667 & 219.444 & 236.667 & 273.125 & 312.083 \\
Lubricant 16 & 190.000 & 194.500 & 215.000 & 245.227 & 291.250 \\
\hline
\end{tabular}

Tabel 3 rincian biaya pemesanan rata-rata mengalami kenaikan karena biaya yang dikeluarkan perusahaan mengikuti dari kebutuhan Raw Materialyang setiap tahunya mengalami kenaikan kebutuhan.

Berikut ini rincian biaya penyimpanan Raw Material dapat dilihat pada tabel dibawah ini:

Tabel 4. Biaya Penyimpanan

\begin{tabular}{lcc}
\hline \multicolumn{1}{c}{ Raw material } & Price per unit & Storage Costs \\
\hline PVC 66 & $\mathrm{Rp} 35.500$ & $\mathrm{Rp} 887,50$ \\
Stabilizer & $\mathrm{Rp} 36.750$ & $\mathrm{Rp} 918,75$ \\
PVC 71 & $\mathrm{Rp} 35.300$ & $\mathrm{Rp} 882,50$ \\
Lubricant 15 & $\mathrm{Rp} 14.500$ & $\mathrm{Rp} 362,50$ \\
Lubricant 16 & $\mathrm{Rp} 48.400$ & $\mathrm{Rp} 1.210,00$ \\
\hline
\end{tabular}


Biaya penyimpanan yang harus ditangung perusahaan selama penyimpanan telah ditentukan yaitu $2,5 \%$ dari harga setiap bahan baku Dalam menghitung $E O Q$ terlebih dahulu harus diketahui biaya pesan dan biaya simpan setiap bahan baku [8].

\subsection{Hasil Perhitungan Metode EOQ Menggunakan POM QM V5.2 For Windows}

Tabel 5. Hasil Perhitungan PVC66 Menggunakan POM QM

\begin{tabular}{|c|c|c|c|}
\hline Parameter & Value & Parameter & Value \\
\hline Demand rate $(D)$ & 39.910 .840 & Optimal order quantity $\left(Q^{*}\right)$ & 228.671 \\
\hline Setup/ordering $\operatorname{cost}(S)$ & 581.391 & Maximum Inventory Level (Imax) & 228.671 \\
\hline $\begin{array}{l}\text { Holding/carrying } \\
\text { cost(H)@2,5\% }\end{array}$ & 887,5 & Average inventory & 114.335 \\
\hline Unit cost & 35.500 & Orders per period(year) & 174,53 \\
\hline Days per year $(D / d)$ & 240 & Annual Setup cost & 101.472 .600 \\
\hline Daily demand rate & 166.295 & Annual Holding cost & 101.472 .600 \\
\hline Lead time (in days) & 5 & $\begin{array}{l}\text { Total Inventory (Holding }+ \text { Setup) } \\
\text { Cost }\end{array}$ & 202.945 .200 \\
\hline \multirow[t]{3}{*}{ Safety stock } & - & Unit costs $(P D)$ & 1.416 .835 .000 .000 \\
\hline & & Total Cost (including units) & 1.417.038.000.000 \\
\hline & & Reorder point & 831.475 units \\
\hline
\end{tabular}

Hasil perhitungan POM QM V5.2 For Windows yang ditunjukan pada Tabel 5 pada bahan baku PVC 66 menunjukan Optimal Order Quantity sebesar 228.670 units, Average Inventory 114.335 units, Orders Per Period(year) 175 kali, Reorder Point 831.475 units[9].

Tabel 6. Hasil Perhitungan Stabilizer Menggunakan POM QM

\begin{tabular}{|c|c|c|c|}
\hline Parameter & Value & Parameter & Value \\
\hline Demand rate $(D)$ & 18.742 & Optimal order quantity $\left(Q^{*}\right)$ & $5.683,23$ \\
\hline Setup/ordering cost(S) & 791.667 & $\begin{array}{r}\text { Maximum Inventory Level } \\
\text { (Imax) }\end{array}$ & $5.683,23$ \\
\hline Holding/carrying cost(H)@2,5\% & 918,75 & Average inventory & $2.841,62$ \\
\hline Unit cost & 36.750 & Orders per period(year) & 3,3 \\
\hline Days per year $(D / d)$ & 240,28 & Annual Setup cost & $2.610 .736,00$ \\
\hline Daily demand rate & 78 & Annual Holding cost & $2.610 .736,00$ \\
\hline Lead time (in days) & 5 & $\begin{array}{r}\text { Total Inventory (Holding + } \\
\text { Setup) Cost }\end{array}$ & $5.221 .472,00$ \\
\hline \multirow[t]{3}{*}{ Safety stock } & 0 & Unit costs $(P D)$ & 688.768 .500 \\
\hline & & Total Cost (including units) & 693.990 .000 \\
\hline & & Reorder point & 390 units \\
\hline
\end{tabular}

Hasil perhitungan POM QM V5.2 For Windows yang ditunjukan pada Tabel 6 pada bahan baku Stabilizer menunjukan Optimal Order Quantity sebesar 5.683 units, Average Inventory 2.842 units, Orders Per Period(year) 3 kali, Reorder Point 390 units. 
IJAI (Indonesian Journal of Applied Informatics)

Vol. 5 No.1 Tahun 2020 pISSN: 2548-3846, elSSN: 2598-5981

\begin{tabular}{|c|c|c|c|}
\hline \multicolumn{4}{|c|}{ Tabel 7. Hasil Perhitungan PVC 71 Menggunakan POM QM } \\
\hline Parameter & Value & Parameter & Value \\
\hline Demand rate(D) & 13.800 .250 & Optimal order quantity $\left(Q^{*}\right)$ & $133.551,60$ \\
\hline Setup/ordering cost(S) & 570.290 & $\begin{array}{r}\text { Maximum Inventory Level } \\
\text { (Imax) }\end{array}$ & $133.551,60$ \\
\hline Holding/carrying cost(H)@2,5\% & 882,5 & Average inventory & $66.775,80$ \\
\hline Unit cost & 35.300 & Orders per period(year) & 103,3 \\
\hline Days per year $(D / d)$ & 240 & Annual Setup cost & 58.929 .630 \\
\hline Daily demand rate & 57.501 & Annual Holding cost & 58.929 .630 \\
\hline Lead time (in days) & 5 & $\begin{array}{r}\text { Total Inventory (Holding }+ \\
\text { Setup) Cost }\end{array}$ & 117.859 .300 \\
\hline Safety stock & 0 & Unit costs $(P D)$ & 487.148 .800 .000 \\
\hline & & Total Cost (including units) & 487.266 .700 .000 \\
\hline & & Reorder point & 287.505 units \\
\hline
\end{tabular}

Hasil perhitungan POM QM V5.2 For Windows yang ditunjukan pada Tabel 7 pada bahan baku PVC 71 menunjukan Optimal Order Quantity sebesar 133.552 units, Average Inventory 66.776 units, Orders Per Period(year) 103 kali, Reorder Point 287.505 units.

Tabel 8. Hasil Perhitungan Lubricant 16 Menggunakan POM QM

\begin{tabular}{|c|c|c|c|}
\hline Parameter & Value & Parameter & Value \\
\hline Demand rate(D) & 7.523 & Optimal order quantity $\left(Q^{*}\right)$ & $1.537,07$ \\
\hline Setup/ordering cost(S) & 190.000 & $\begin{array}{r}\text { Maximum Inventory Level } \\
\text { (Imax) }\end{array}$ & $1.537,07$ \\
\hline Holding/carrying cost(H)@2,5\% & 1210 & Average inventory & 768,54 \\
\hline Unit cost & 48.400 & Orders per period(year) & 4,89 \\
\hline Days per year (D/d) & 242,68 & Annual Setup cost & $929.929,50$ \\
\hline Daily demand rate & 31 & Annual Holding cost & $929.929,40$ \\
\hline Lead time (in days) & 5 & $\begin{array}{r}\text { Total Inventory (Holding + } \\
\text { Setup) Cost }\end{array}$ & 1.859 .859 \\
\hline \multirow[t]{3}{*}{ Safety stock } & 0 & Unit costs $(P D)$ & 364.113 .200 \\
\hline & & Total Cost (including units) & 365.973 .100 \\
\hline & & Reorder point & 155 units \\
\hline
\end{tabular}

Hasil perhitungan POM QM V5.2 For Windows yang ditunjukan pada Tabel 8 pada bahan baku Lubricant 16 menunjukan Optimal Order Quantity sebesar 1.537 units, Average Inventory 767 units, Orders Per Period(year) 5 kali, Reorder Point 155 units.

Tabel 9. Hasil Perhitungan Lubricant 15 Menggunakan POM QM

\begin{tabular}{lrrr}
\hline Parameter & Value & Parameter & Value \\
\hline Demand rate $(D)$ & 18.486 & Optimal order quantity $\left(Q^{*}\right)$ & $4.122,94$ \\
Setup/ordering cost $(S)$ & 166.667 & Maximum Inventory Level & (Imax) \\
Holding/carrying cost $(H) @ 2,5 \%$ & 362,5 & Average inventory & $2.122,94$ \\
Unit cost & 14.500 & Orders per period(year) & $4,061,47$ \\
Days per year (D/d) & 240,08 & Annual Setup cost & $747.283,30$ \\
Daily demand rate & 77 & Annual Holding cost & $747.283,30$ \\
Lead time (in days) & 5 & Total Inventory (Holding + & $1.494 .567,00$ \\
Safety stock & 0 & Setup) Cost & 268.047 .000 \\
& & Unit costs (PD) & \\
& & Total Cost (including units) & 269.541 .600 \\
& & Reorder point & 385 units \\
\hline
\end{tabular}

54 | IJAI (Indonesian Journal of Applied Informatics) 
Hasil perhitungan POM QM V5.2 For Windows yang ditunjukan pada Tabel 9 pada bahan baku Lubricant 15 menunjukan Optimal Order Quantity sebesar 1.123 units, Average Inventory 2.061 units, Orders Per Period(year) 5 kali, Reorder Point 385 units.

\subsection{Hasil Menggunakan Microsoft Exce/Dan Manual Rumus}

Tabel 10. Hasil perhitungan Manual

\begin{tabular}{|c|c|c|}
\hline Comparison & Parameter & Result \\
\hline \multirow{7}{*}{ Company policy } & Demand rate(D) & 39.910 .835 \\
\hline & Annual Setup cost & 154.650 .000 \\
\hline & Holding $\operatorname{cost}(H)$ & $2,50 \%$ \\
\hline & Unit cost & 35.500 \\
\hline & Days per year $(D / d)$ & 240 \\
\hline & Daily demand rate & $166.295,14$ \\
\hline & Lead time (in days) & 5 \\
\hline \multirow{10}{*}{$\begin{array}{l}\text { Microsoft Excel } \\
\text { Calculation Results }\end{array}$} & Optimal order quantity $\left(Q^{\star}\right)$ & $228.670,63$ \\
\hline & Maximum Inventory Level (Imax) & $228.670,63$ \\
\hline & Average inventory & $114.335,32$ \\
\hline & Orders per period(year) & 175.53 \\
\hline & Annual Setup cost & 101.472.599.16 \\
\hline & Annual Holding cost & 101.472.592.06 \\
\hline & Total Inventory(Holding+Setup)Cost & 202.945.191.22 \\
\hline & Unit costs (PD) & 1.416 .834 .820 .000 \\
\hline & Total Cost & 1.417.037.765.191.20 \\
\hline & Reorder point (Units) & 831.475 .7 \\
\hline
\end{tabular}

$$
\begin{aligned}
\text { Optimal order quantity }\left(Q^{*}\right) & =\sqrt{\frac{(2 . S . D)}{\mathrm{H}}} \\
& =\sqrt{\frac{(2 \times 581.391 \times 39.910 .840)}{887.5}} \\
& =228.670,63 \\
& =\sqrt{\frac{(2 . S . D)}{\mathrm{H}}} \\
& =\sqrt{\frac{(2 \times 581.391 \times 39.910 .840)}{887.5}} \\
& =228.670,63 \\
\text { Average inventory }(A I)=\frac{Q^{*}}{2} & =\frac{228.670,63}{2} \\
& =114.335,31 \\
& =\frac{D}{Q *} \\
\text { Order per period(Opp) } & =\frac{39.910 .835}{228.670,63} \\
& =175.53 \\
& =\frac{(\text { S.D })}{Q *} \\
\text { Annual setup cost }(A S C) & =\frac{(581.391 \times 39.910 .840)}{228.670,63} \\
& =101.472 .599 .16
\end{aligned}
$$

IJAI (Indonesian Journal of Applied Informatics) | 55 


$$
\begin{aligned}
& \text { Annual holding cost }(A H C) \quad=\frac{(\mathrm{H} . \mathrm{Q} *)}{2} \\
& =\frac{(887,5 \times 228.670,63)}{2} \\
& =101.472 .592 .06 \\
& \text { Inventory Cost }=\mathrm{ASC}+\mathrm{AHC} \\
& =101.472 .599 .16+101.472 \cdot 592.06 \\
& =202.945 .191 .22 \\
& \text { Unit costs }(P D) \quad=P . D \\
& =35.500 \times 39.910 .840 \\
& =1.416 .834 .820 .000 \\
& =1.416 .834 .820 .000+202.945 \cdot 191 \cdot 22 \\
& =1.417 .037 .765 .191 .20 \\
& \text { Reoder point } \quad=\mathrm{d} . \mathrm{L} \\
& =166.295,14 \times 5 \\
& =831.475 .7
\end{aligned}
$$

Berdasarkan perhitungan matematik di atas Optimal order quantity yaitu $228.670,63 \mathrm{~kg}$ jumlah tersebut tidak ada selisih dengan jumlah Inventory maximum yaitu 228.670,63 kg. Jumlah Average inventoryatau rata-rata persediaan sesuai dengan rumus yaitu optimal order dibagi dua dengan hasil 114.335,31 Kg. Order per period perhitungan yaitu

\begin{tabular}{|c|c|c|c|c|c|c|c|c|}
\hline \multirow[b]{2}{*}{ Year } & \multicolumn{2}{|c|}{ Company policy } & \multicolumn{2}{|c|}{$\begin{array}{c}\text { POM QM Calculation } \\
\text { Results For Windows } \\
\text { V5.2 }\end{array}$} & \multicolumn{2}{|c|}{$\begin{array}{c}\text { Excel Calculation Results } \\
\text { Using Manual Formulas }\end{array}$} & \multirow[b]{2}{*}{ Difference } & \multirow[b]{2}{*}{$\begin{array}{c}\text { Percentage } \\
\text { Difference }\end{array}$} \\
\hline & $\begin{array}{c}\text { Optimal } \\
\text { order } \\
\text { quantity } \\
\left(Q^{*}\right) \\
(\mathrm{Kg})\end{array}$ & $\begin{array}{l}\text { Annual } \\
\text { Setup cost } \\
\quad(R p)\end{array}$ & $\begin{array}{l}\text { Optimal } \\
\text { order } \\
\text { quantity } \\
\left(Q^{*}\right)(K g)\end{array}$ & $\begin{array}{l}\text { Annual } \\
\text { Setup cost } \\
\quad(R p)\end{array}$ & $\begin{array}{l}\text { Optimal } \\
\text { order } \\
\text { quantity } \\
\left(Q^{*}\right)(K g)\end{array}$ & $\begin{array}{l}\text { Annual } \\
\text { Setup cost } \\
\quad(R p)\end{array}$ & & \\
\hline 2015 & - & 154.650 .000 & 228.671 & 101.472 .600 & 228.671 & 101.472 .600 & 53.177 .400 & $34 \%$ \\
\hline 2016 & - & 185.100 .000 & 250.264 & 111.054 .600 & 250.264 & 111.054 .600 & 74.045 .400 & $40 \%$ \\
\hline 2017 & - & 215.590 .000 & 270.137 & 119.873 .200 & 270.137 & 119.873 .200 & 95.716 .800 & $44 \%$ \\
\hline 2018 & - & 245.927 .500 & 288.121 & 127.853 .600 & 288.121 & 127.853 .600 & 118.073 .900 & $48 \%$ \\
\hline 2019 & - & 276.155 .000 & 305.490 & 135.561 .300 & 305.490 & 135.561 .300 & 140.593 .700 & $51 \%$ \\
\hline
\end{tabular}
kebutuhan bahan baku di bagi dengan optimal order dengan hasil yaitu 175.53 dibulatkan menjadi 176 kali dalam satu tahun.

Annual setup cost adalah biaya pemesanan selama satu tahun yaitu Rp 101.472.599.16. Annual holding cost

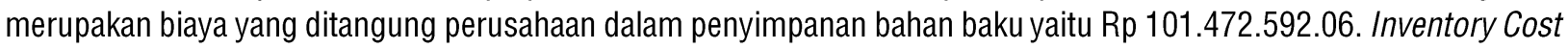
adalah jumlah biaya yang dikeluarkan perusahaan dalam persediaan yaitu $\mathrm{Rp}$ 202.945.191.22. Unit costs merupakan biaya yang dikeluarkan untuk bahan baku cara menghitungnya yaitu harga per unit dikalikan kebutuhan hasilnya $\mathrm{Rp}$ 1.417.037.765.191.20. Total Cost adalah total biaya yang dikeluarkan perusahan yang meliputi Unit costs ditambah dengan Inventory Cost hasilnya yaitu $\mathrm{Rp}$ 1.417.037.765.191.20. Reoder point adalah titik pemesanan kembali dengan perhitungan kebutuhan perhari dikalikan dengan lead time sehingga diperoleh jumlah $831.475 .7 \mathrm{Kg}$ artinya jika persediaan menujukan jumlah tersebut maka perusahaan harus melakukan pemesanan bahan baku.

\section{Evaluasi Hasil}

Evaluasi hasil dalam penelitian ini yaitu membandingan hasil perhitungan antara antara kebijakan perusahaan dengan hasil perhitungan EOQ Menggunakan POM For Windows dan menggunakan Excel selama lima tahun.

Tabel 11. Hasil Perbandingan perhitungan bahan baku PVC 66 


\begin{tabular}{llllllll}
\hline & & & & & & \\
Average & 215.484 .50 & & 119.163 .06 & & 119.163 .06 & & \\
& 0 & 268.536 & 0 & 268.536 & 0 & 96.321 .440 & $44 \%$ \\
\hline
\end{tabular}

Hasil perhitungan di atas Annual Setup Cost kebijakan perusahaan dengan rata-rata selama lima tahun Rp 215.484.500,00, hasil perhitungan POM QM dengan rata-rata Rp 119.163.060,00 kemudian hasil perhitungan secara manual menggunakan rumus diaplikasikan menggunakan Microsoft Excel tidak jauh berbeda dengan hasil perhitungan POM QM sehingga selisih biaya rata-rata selama lima tahun $\mathrm{Rp} 96.321 .440,00$ atau menghemat biaya rata-rata $44 \%$ lebih rendah dibandingakan dengan kebijakan perusahaan, Optimal ordersetiap pemesanan yaitu $268.536 .48 \mathrm{Kg}$.

Tabel 12. Hasil Perbandingan perhitungan bahan baku Stabilizer

\begin{tabular}{|c|c|c|c|c|c|c|c|c|}
\hline \multirow[b]{2}{*}{ Year } & \multicolumn{2}{|c|}{ Company policy } & \multicolumn{2}{|c|}{$\begin{array}{c}\text { POM QM Calculation } \\
\text { Results For Windows V5.2 }\end{array}$} & \multicolumn{2}{|c|}{$\begin{array}{c}\text { Excel Calculation Results } \\
\text { Using Manual Formulas }\end{array}$} & \multirow[b]{2}{*}{ Difference } & \multirow[b]{2}{*}{$\begin{array}{l}\text { Percentage } \\
\text { Difference }\end{array}$} \\
\hline & $\begin{array}{c}\text { Optimal } \\
\text { order } \\
\text { quantity } \\
\left(Q^{*}\right) \\
(\mathrm{Kg})\end{array}$ & $\begin{array}{l}\text { Annual } \\
\text { Setup cost } \\
\quad(R p)\end{array}$ & $\begin{array}{l}\text { Optimal } \\
\text { order } \\
\text { quantity } \\
\left(Q^{*}\right)(K g)\end{array}$ & $\begin{array}{l}\text { Annual } \\
\text { Setup cost } \\
\text { (Rp) }\end{array}$ & $\begin{array}{l}\text { Optimal } \\
\text { order } \\
\text { quantity } \\
\left(Q^{\star}\right)(\mathrm{Kg})\end{array}$ & $\begin{array}{l}\text { Annual } \\
\text { Setup cost } \\
\text { (Rp) }\end{array}$ & & \\
\hline 2015 & - & 4.750 .000 & 5.683 & 2.610 .736 & 5.683 & 2.610 .700 & 2.139 .264 & $45 \%$ \\
\hline 2016 & - & 6.800 .000 & 6.714 & 3.084 .124 & 6.714 & 3.084 .125 & 3.715 .876 & $55 \%$ \\
\hline 2017 & - & 7.400 .000 & 6.733 & 3.092 .801 & 6.733 & 3.092 .800 & 4.307.199 & $58 \%$ \\
\hline 2018 & - & 10.225 .000 & 8.216 & 3.774 .276 & 8.216 & 3.774 .276 & 6.450 .724 & $63 \%$ \\
\hline 2019 & - & 10.355 .000 & 8.257 & 3.793 .268 & 8.257 & 379.270 & 6.561 .732 & $63 \%$ \\
\hline \multicolumn{2}{|c|}{ Average } & 7.906 .000 & 7.121 & 3.271 .041 & 7.121 & 3.271 .041 & 4.634.959 & $57 \%$ \\
\hline
\end{tabular}

Hasil perhitungan di atas Annual Setup Cost kebijakan perusahaan dengan rata-rata selama lima tahun $\mathrm{Rp}$ 7.906.000,00 sedangkan hasil perhitungan POM QM dengan rata-rata $\mathrm{Rp} 3.271 .041,00$ kemudian hasil perhitungan secara manual menggunakan rumus diaplikasikan menggunakan Microsoft Excel tidak jauh berbeda dengan hasil

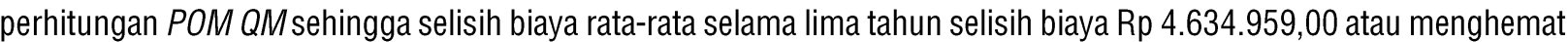
biaya rata-rata $57 \%$ lebih rendah dibandingakan dengan kebijakan perusahaan, Optimal order setiap pemesanan yaitu $7.120,63 \mathrm{Kg}$.

Tabel 13. Hasil Perbandingan perhitungan bahan baku PVC 71

\begin{tabular}{|c|c|c|c|c|c|c|c|c|}
\hline \multirow[b]{2}{*}{ Year } & \multicolumn{2}{|c|}{ Company policy } & \multicolumn{2}{|c|}{$\begin{array}{c}\text { POM QM Calculation } \\
\text { Results For Windows V5.2 }\end{array}$} & \multicolumn{2}{|c|}{$\begin{array}{c}\text { Excel Calculation Results } \\
\text { Using Manual Formulas }\end{array}$} & \multirow[b]{2}{*}{ Difference } & \multirow{2}{*}{$\begin{array}{c}\text { Percentage } \\
\text { Difference }\end{array}$} \\
\hline & $\begin{array}{c}\text { Optimal } \\
\text { order } \\
\text { quantity } \\
\left(Q^{*}\right) \\
(K g)\end{array}$ & $\begin{array}{c}\text { Annual Setup } \\
\text { cost (Rp) }\end{array}$ & $\begin{array}{l}\text { Optimal } \\
\text { order } \\
\text { quantity } \\
\left(Q^{*}\right)(K g)\end{array}$ & $\begin{array}{l}\text { Annual } \\
\text { Setup cost } \\
\text { (Rp) }\end{array}$ & $\begin{array}{l}\text { Optimal } \\
\text { order } \\
\text { quantity } \\
\left(Q^{*}\right)(K g)\end{array}$ & $\begin{array}{l}\text { Annual } \\
\text { Setup cost } \\
\quad(R p)\end{array}$ & & \\
\hline 2015 & - & 78.700 .000 & $133.551,60$ & 58.929 .630 & $133.551,60$ & 58.929 .630 & 19.770 .370 & $25 \%$ \\
\hline 2016 & - & 105.600 .000 & $154.780,20$ & 68.296 .770 & $154.780,00$ & 68.296 .770 & 37.303 .230 & $35 \%$ \\
\hline 2017 & - & 121.500 .000 & $166.032,40$ & 73.261 .820 & $166.032,40$ & 73.261 .800 & 48.238 .180 & $40 \%$ \\
\hline 2018 & - & 145.100 .000 & $181.477,60$ & 80.076 .980 & $181.477,60$ & 80.076 .980 & 65.023 .020 & $45 \%$ \\
\hline 2019 & - & 160.500 .000 & $191.075,30$ & 84.311 .970 & $191.075,00$ & 84.311 .980 & 76.188 .030 & $47 \%$ \\
\hline & rage & 122.280 .000 & $\begin{array}{l}165.383,4 \\
2\end{array}$ & 72.975 .434 & $165.383,42$ & 72.975 .434 & 49.304 .566 & $38 \%$ \\
\hline
\end{tabular}

Hasil perhitungan di atas Annual Setup Cost kebijakan perusahaan dengan rata-rata selama lima tahun Rp IJAI (Indonesian Journal of Applied Informatics) | 57 
1 22.280.000,00 sedangkan hasil perhitungan POM QM dengan rata-rata Rp 72.975.434,00 kemudian hasil perhitungan secara manual menggunakan rumus di aplikasikan menggunakan Microsoft Excel tidak jauh berbeda dengan hasil

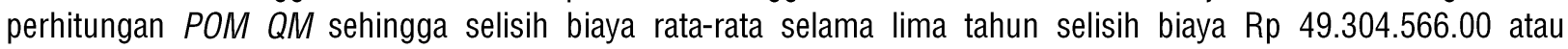
menghemat biaya rata-rata $38 \%$ lebih rendah dibandingakan dengan kebijakan perusahaan, Optimal order setiap pemesanan yaitu $165.383,42 \mathrm{Kg}$.

Tabel 14. Hasil Perbandingan perhitungan bahan baku Lubricant 16

\begin{tabular}{|c|c|c|c|c|c|c|c|c|}
\hline \multirow[b]{2}{*}{ Year } & \multicolumn{2}{|c|}{ Company policy } & \multicolumn{2}{|c|}{$\begin{array}{c}\text { POM QM Calculation } \\
\text { Results For Windows } \\
\text { V5.2 }\end{array}$} & \multicolumn{2}{|c|}{$\begin{array}{l}\text { Excel Calculation Results } \\
\text { Using Manual Formulas }\end{array}$} & \multirow[b]{2}{*}{ Difference } & \multirow[b]{2}{*}{$\begin{array}{l}\text { Percentage } \\
\text { Difference }\end{array}$} \\
\hline & $\begin{array}{c}\text { Optimal } \\
\text { order } \\
\text { quantity } \\
\left(Q^{*}\right) \\
(\mathrm{Kg})\end{array}$ & $\begin{array}{l}\text { Annual } \\
\text { Setup cost } \\
\text { (Rp) }\end{array}$ & $\begin{array}{c}\text { Optimal } \\
\text { order } \\
\text { quantity } \\
\left(Q^{*}\right) \\
(K g)\end{array}$ & $\begin{array}{l}\text { Annual Setup } \\
\text { cost (Rp) }\end{array}$ & $\begin{array}{c}\text { Optimal } \\
\text { order } \\
\text { quantity } \\
\left(Q^{*}\right)(\mathrm{Kg})\end{array}$ & $\begin{array}{l}\text { Annual Setup } \\
\text { cost (Rp) }\end{array}$ & & \\
\hline 2015 & - & 1.140 .000 & 1.537 & 929.930 & 1.537 & 929.930 & 210.071 & $18 \%$ \\
\hline 2016 & - & 1.945 .000 & 1.743 & 1.054 .472 & 1.743 & 1.054 .630 & 890.528 & $46 \%$ \\
\hline 2017 & - & 2.580 .000 & 2.309 & 1.396 .827 & 2.309 & 1.396 .800 & 1.183 .173 & $46 \%$ \\
\hline 2018 & - & 2.697 .500 & 2.332 & 1.410 .773 & 2.332 & 1.410 .771 & 1.286 .727 & $48 \%$ \\
\hline 2019 & - & 2.330 .000 & 2.566 & 1.552 .295 & 2.566 & 1.552 .300 & 777.705 & $33 \%$ \\
\hline \multicolumn{2}{|c|}{ Average } & 2.138 .500 & 2.097 & 1.268 .859 & 2.097 & 1.268 .859 & 869.641 & $38 \%$ \\
\hline
\end{tabular}

Hasil perhitungan di atas Annual Setup Cost kebijakan perusahaan dengan rata-rata selama lima tahun $\mathrm{Rp}$ 2.138.500,00 sedangkan hasil perhitungan POM QM dengan rata-rata $\mathrm{Rp} 1.268 .859,00$ kemudian hasil perhitungan secara manual menggunakan rumus diaplikasikan menggunakan Microsoft Excel tidak jauh berbeda dengan hasil perhitungan POM QM sehingga selisih biaya rata-rata selama lima tahun selisih biaya Rp 869.641,00 atau menghemat biaya rata-rata $38 \%$ lebih rendah dibandingakan dengan kebijakan perusahaan, Optimal order setiap pemesanan yaitu $2.097,00 \mathrm{Kg}$.

Tabel 15. Hasil Perbandingan perhitungan bahan baku Lubricant 15

\begin{tabular}{|c|c|c|c|c|c|c|c|c|}
\hline \multirow[b]{2}{*}{ Year } & \multicolumn{2}{|c|}{ Company policy } & \multicolumn{2}{|c|}{$\begin{array}{c}\text { POM QM Calculation } \\
\text { Results For Windows } \\
\text { V5.2 }\end{array}$} & \multicolumn{2}{|c|}{$\begin{array}{l}\text { Excel Calculation Results } \\
\text { Using Manual Formulas }\end{array}$} & \multirow[b]{2}{*}{ Difference } & \multirow[b]{2}{*}{$\begin{array}{c}\text { Percentage } \\
\text { Difference }\end{array}$} \\
\hline & $\begin{array}{c}\text { Optimal } \\
\text { order } \\
\text { quantity } \\
\left(Q^{*}\right) \\
(K g)\end{array}$ & $\begin{array}{l}\text { Annual } \\
\text { Setup cost } \\
\text { (Rp) }\end{array}$ & $\begin{array}{c}\text { Optimal } \\
\text { order } \\
\text { quantity } \\
\left(Q^{*}\right)(K g)\end{array}$ & $\begin{array}{l}\text { Annual } \\
\text { Setup cost } \\
\text { (Rp) }\end{array}$ & $\begin{array}{c}\text { Optimal } \\
\text { order } \\
\text { quantity } \\
\left(Q^{*}\right)(K g)\end{array}$ & $\begin{array}{l}\text { Annual } \\
\text { Setup cost } \\
\text { (Rp) }\end{array}$ & & \\
\hline 2015 & - & 2.000 .000 & 4.123 & 747.283 & 4.123 & 747.283 & 1.252 .717 & $63 \%$ \\
\hline 2016 & - & 1.975 .000 & 4.603 & 834.248 & 4.603 & 834.248 & 1.140 .752 & $58 \%$ \\
\hline 2017 & - & 2.840 .000 & 6.112 & 1.107 .853 & 6.112 & 1.107 .853 & 1.732 .147 & $61 \%$ \\
\hline 2018 & - & 3.277 .500 & 8.246 & 1.494 .595 & 8.246 & 1.494 .628 & 1.782 .905 & $54 \%$ \\
\hline 2019 & - & 3.745 .000 & 7.367 & 1.335 .264 & 7.367 & 1.335 .264 & 2.409 .736 & $64 \%$ \\
\hline & rage & 2.767 .500 & 6.090 & 1.103 .849 & 6.090 & 1.103 .855 & 1.663 .651 & $60 \%$ \\
\hline
\end{tabular}

Hasil perhitungan di atas Annual Setup Cost kebijakan perusahaan dengan rata-rata selama lima tahun Rp 2.767.500 sedangkan hasil perhitungan POM QM dengan rata-rata Rp 1.103.849 kemudian hasil perhitungan secara manual menggunakan rumus diaplikasikan menggunakan Microsoft Excel tidak jauh berbeda dengan hasil perhitungan POM QM sehingga selisih biaya rata-rata selama lima tahun selisih biaya $\mathrm{Rp} 1.663 .651$ atau menghemat biaya ratarata $60 \%$ lebih rendah dibandingakan dengan kebijakan perusahaan, Optimal order setiap pemesanan yaitu 6.090 $\mathrm{Kg}[10]$. 


\section{KESIMPULAN}

Berdasarkan hasil hasil penelitian maka dapat ditarik kesimpulan yaitu dari perhitungan metode $A B C$ terdapat lima bahan baku yang masuk kategori A yaitu bahan baku PVC66, Stabilizer, PVC 71, Lubricant 16A, dan Lubricant 15 membutuhkan monitoring sangat ketat. Perusahaan dapat menghemat biaya pemesanan atau Annual Ordering Cost PVC66 menghemat biaya rata-rata $\mathrm{Rp} 96.321 .440,00$ atau 44\%, Stabilizer menghemat biaya rata-rata $\mathrm{Rp} \mathrm{4.634.959,00}$ atau 57\%, PVC 71 menghemat biaya rata-rata Rp 49.304 .566 .00 atau 38\%, Lubricant 16 A menghemat biaya rata-rata Rp 869.640,7 atau 38\%, Lubricant 15 menghemat biaya rata-rata $\mathrm{Rp} \mathrm{1.663.651,38} \mathrm{atau} \mathrm{60 \% .} \mathrm{Optimal} \mathrm{order} \mathrm{quantity}$ PVC 66 268.536,48 Kg, stabilzer 7.120,63 Kg, PVC 71 165.383,42 Kg, Lubricant 16 A $2.097 \mathrm{Kg}$, Lubricant $156.090 \mathrm{Kg}$ . Reorder point PVC $66920.164 \mathrm{Kg}$, Stabilizer $475 \mathrm{Kg}$, PVC $71377.680 \mathrm{Kg}$, Lubricant 16A 245 Lubricant $15588 \mathrm{Kg}$. Hasil penelitian menujukan bahwa Software yang tepat dalam pengendalian persediaan di PT.SMI yaitu POM QM V5.2 For Windows.

\section{UCAPAN TERIMA KASIH}

Penulis mengucapkan terima kasih kepada Sekolah Tinggi Manajemen Informatika dan Komputer Eresha yang telah memberikan keleluasaan kepada peneliti untuk dapat secara langsung menerapkan ilmu yang diperoleh selama belajar dan terus mendukung peneliti dalam menyelesaikan penelitian dari awal sampai akhir dengan hasil penelitian dapat dipublikasi.

\section{DAFTAR PUSTAKA}

[1] F. Ramadhany and S. Supriono, "Analisis Penerapan Sistem Manajemen Mutu ISO 9001:2015 Dalam Menunjang Pemasaran (Studi pada PT Tritama Bina Karya Malang)," J. Adm. Bisnis S1 Univ. Brawijaya, vol. 53, no. 1, pp. 31-38, 2017.

[2] S. Assauri, Management Produksi Indonesia: Fakultas Ekonomi Universitas Indonesia. 2016.

[3] H. J. Weiss, "Quantitative Methods, Production and Operations Management," in Software for Decision Sciences, 2018.

[4] S. A. Kumar and N. Suresh, Production and operations management. New Age International, 2006.

[5] N. Apriyani and A. Muhsin, "Analisis Pengendalian Persediaan Bahan Baku Dengan Metode Economic Order Quantity Dan Kanban Pada Pt Adyawinsa Stamping Industries," Opsi, vol. 10, no. 2, p. 128, 2017, doi: 10.31315/opsi.v10i2.2108.

[6] Sarwandi, Jago Microsoft Excel 2016. In C. Creative, Trik Jitu Menguasai Excel 2016 (p. 1). Jakarta: Elex Media Komputindo. 2017.

[7] J. Junaidi, "Penerapan Metode ABC Terhadap Pengendalian Persediaan Bahan Baku Pada Ud. Mayong Sari Probolinggo," Cap. J. Ekon. dan Manaj., vol. 2, no. 2, p. 158, 2019, doi: 10.25273/capital.v2i2.3988.

[8] E. Indriastiningsih and S. Darmawan, "Analisa Pengendalian Persediaan Sparepart Motor Honda Beat Fi dengan Metode EOQ Menggunakan Peramalan Penjualan Di Graha Karyaahass XY," Din. Tek., vol. 12, no. 2, pp. 2443, 2019, [Online]. Available: https://www.unisbank.ac.id/ojs/index.php/ft1/issue/view/408.

[9] V. Gaspersz, Production planing and inventory control, PT. Gramedia pustaka utama, Jakarta. 2014.

[10] L. J. Krajewski, L. P. Ritzman, and M. K Malhotra, Operations Management:Processes and Supply Chains: Global Edition. 2013. 